\title{
Influence of sowing dates and nitrogen levels on growth, yield and quality of scented rice cv. Pusa Sugandh-3 in Kashmir valley
}

\author{
Sheeraz Ahmad Wani ${ }^{1 *}$, Sameera Qayoom ${ }^{1}$, Mohammad Amin Bhat ${ }^{2}$, Bilal Ahmad Lone ${ }^{1}$, \\ Aijaz Nazir ${ }^{1}$
}

${ }^{1}$ Division of Agronomy, Sher-e-Kashmir University of Agricultural Sciences and Technology of Kashmir, Shalimar-190025 (J\&K), INDIA

${ }^{2}$ Department of Soil Science, CCS Haryana Agricultural University, Hisar- 125004 (Haryana), INDIA

*Corresponding author. E-mail: sheerazwani2@gmail.com

Received: January 13, 2016; Revised received: June 08, 2016; Accepted: August 30, 2016

\begin{abstract}
A field experiment was carried out to determine the optimum sowing date and nitrogen $(\mathrm{N})$ level for the scented rice cv. Pusa Sugandh-3. Twelve treatment combinations of 3 sowing dates, viz., $15^{\text {th }}, 16^{\text {th }}$ and $18^{\text {th }}$ standard meteorological week (SMW) at an interval of 10 days and 4 nitrogen levels ('0', '40', '60' and ' 80 ' $\mathrm{kg} \mathrm{N} \mathrm{ha}^{-1}$ ) were tested randomized in split plot design with three replications. Significant highest plant height $(98.56 \mathrm{~cm})$, tillers $\mathrm{m}^{-2}(333.41)$, dry matter $\left(98.38 \mathrm{q} \mathrm{ha}^{-1}\right)$, panicles $\mathrm{m}^{-2}(310.05)$, spikelets panicle ${ }^{-1}(130.25)$ and grains panicle ${ }^{-1}(98.55)$, grain yield $\left(45.2 \mathrm{q} \mathrm{ha}^{-1}\right)$, harvest index $(41.20 \%)$, head rice recovery $(47.5 \%)$ and B:C ratio (3.03) were recorded for the early sown $15^{\text {th }}$ SMW crop. Among the different nitrogen levels tested significant highest plant height $(98.12 \mathrm{~cm})$, tillers $\mathrm{m}^{-2}(342.33)$ dry matter $\left(100.68 \mathrm{q} \mathrm{ha}^{-1}\right)$, panicles $\mathrm{m}^{-2}(321.83)$, spikelets panicle ${ }^{-1}(132.83)$ grains panicle ${ }^{-1}$ (96.79), grain yield (48.0 q ha $\left.{ }^{-1}\right)$, harvest index (42.68\%), head rice recovery $(44.54 \%)$ and $\mathrm{B}: \mathrm{C}$ ratio (3.38) were recorded with the application of $80 \mathrm{~kg} \mathrm{~N} \mathrm{ha}^{-1}$. Therefore, the variety, Pusa Sugandh-3 should be sown earlier in season from $15^{\text {th }}$ to $16^{\text {th }}$ SMW and with nitrogen application of $60-80 \mathrm{~kg} \mathrm{~N} \mathrm{ha}^{-1}$ for realizing economically higher grain yield and profit under the temperate climatic conditions of Kashmir valley.
\end{abstract}

Keywords: Grain yield, Head rice, Nitrogen levels, Pusa Sugandh-3, Sowing dates

\section{INTRODUCTION}

Most of the basmati varieties grown in our country including the state Jammu and Kashmir are traditional varieties, which are tall statured, weak stemmed, disease susceptible and non- responsive to fertilizers, resulting in their lower yield, but are recognized for their reputed aroma. However, some new high yielding semi dwarf basmati varieties have been released which have revolutionized the basmati rice production of the country. Recently some of these high yielding varieties like Pusa Basmati-1, Pusa Sugandh-2 and Pusa Sugandh-3 have also been introduced in the valley and evaluated for their performance under temperate climatic conditions. Among these Pusa Sugandh-3 has been found to perform comparatively better than other varieties and in terms of yield potential, disease resistancce and duration. The higher sterility percentage noted for the variety is attributed to the lower temperature during anthesis to grain filling stage in the valley, when sown at dates recommended for the non-aromatic types. Also the higher fertilizer doses especially nitrogen recommended for non-aromatic types do not suit the basmati types. Higher nitrogen doses produce crop of poor grain quality, predisposes crop to more disease attacks, increases the crop duration and also exposes the vari- ety to the lower temperature stress prevalent in valley late in the season.

Since rice yield and quality are not only controlled by genetic factors, but are also largely influenced by environmental factors (Gao and Zhang, 1994), such as light, temperature, soil type, soil water, cultivation measures, etc. (Hiroyuki et al., 2002), which can be manipulated to optimum level for higher crop yields through different management factors of which sowing date and nitrogen fertilization are of prime importance. Time of sowing assumes greater importance, owing to shorter growing season of 140-145 days available under Kashmir valley conditions. The important growth phases of rice crop especially the grain filling stage coincides with very low temperature resulting in very high sterility percentage, when sown late (Hussain et al., 2009).

Nitrogen is one of the most important nutritional elements for the higher productivity of cereal crops and a major factor that limits agricultural yields (Balasubramanian et al., 2000 and Islam, 2009). Nitrogen absorbed by rice during the vegetative growth stages contributes in growth during reproduction and grain-filling through translocation (Norman et al., 1992; Bufogle et al., 1997). The application of nitrogen fertilizer either in excess or less than optimum rate affects both yield and quality of rice to remarkable 
extent, hence proper management of crop nutrition is of immense importance (Manzoor et al., 2006). Recommendation on nitrogen requirement and planting dates for growing coarse rice is available, but in case of basmati rice such information is lacking. The variety Pusa Sugandh-3 being comparatively new to the valley, therefore much work has not been done yet on these aspects and as such there is lack of information of these agronomic treatments on the yield of this variety. So keeping in view these facts, the experiment was conducted to synchronize the important growth stages of the scented rice with the optimum environmental conditions after application of proper nitrogen dose in order to get timely matured crop with higher yields and better quality.

\section{MATERIALS AND METHODS}

The study was conducted at the Agronomy Farm of Sher-e-Kashmir University of Agricultural Sciences and Technology of Kashmir during summer season 2013. The study area is situated at $34^{\circ} 05^{\prime} \mathrm{N}$ latitude and $74^{\circ} 89^{\prime}$ East longitude having an altitude of 1587 $\mathrm{m}$ above mean sea level. The mean temperatures ranged from $13.11{ }^{\circ} \mathrm{C}$ and $26.90{ }^{\circ} \mathrm{C}$, respectively. Twelve treatment combinations $\left(\mathrm{D}_{1} \mathrm{~N}_{0}, \mathrm{D}_{1} \mathrm{~N}_{1}, \mathrm{D}_{1} \mathrm{~N}_{2}\right.$, $\mathrm{D}_{1} \mathrm{~N}_{3}, \mathrm{D}_{2} \mathrm{~N}_{0}, \mathrm{D}_{2} \mathrm{~N}_{1}, \mathrm{D}_{2} \mathrm{~N}_{2}, \mathrm{D}_{2} \mathrm{~N}_{3}, \mathrm{D}_{3} \mathrm{~N}_{0}, \mathrm{D}_{3} \mathrm{~N}_{1}, \mathrm{D}_{3} \mathrm{~N}_{2}$, $\mathrm{D}_{3} \mathrm{~N}_{3}$ ) of 3 sowing dates, viz., $15^{\text {th }}, 16^{\text {th }}$ and $18^{\text {th }}$ Standard meteorological week (SMW) at an interval of 10 days and 4 nitrogen levels (' 0 ', '40', '60' and ' 80 ' $\mathrm{kg}$ $\mathrm{N} \mathrm{ha}{ }^{-1}$ ), respectively were tested and randomized in split plot design with three replications. The soil of the experimental field was silty clay loam in texture with neutral $\mathrm{pH}$, normal electrical conductivity $\left(0.23 \mathrm{dSm}^{-}\right.$ ${ }^{1}$ ), medium available nitrogen (407.68 $\left.\mathrm{kg} \mathrm{ha}^{-1}\right)$, low available potassium (178.08 $\left.\mathrm{kg} \mathrm{ha}^{-1}\right)$, high available phosphorus (26.57 kg ha-1) and organic carbon $(0.95 \%)$. The nursery was raised in low polythene tunnels during a period of low temperature $\left(<10^{\circ} \mathrm{C}\right)$. Forty days old seedlings were transplanted at a spacing of 15 $\mathrm{cm} \times 15 \mathrm{~cm}$. A uniform dose of phosphorous $(\mathrm{P})$, potassium $(\mathrm{K})$ and zinc $(\mathrm{Zn})$ at the rate of $60 \mathrm{~kg} \mathrm{P}_{2} \mathrm{O}_{5}, 40$ $\mathrm{kg} \mathrm{K} 2 \mathrm{O}$ and $15 \mathrm{~kg} \mathrm{ZnSO}_{4} \mathrm{ha}^{-1}$ was applied in all plots. The nitrogen was applied as per treatments in three splits. Entire quantity of $\mathrm{P}, \mathrm{K}$ and $\mathrm{Zn}$ and $50 \% \mathrm{~N}$ was applied before transplanting and the remaining nitrogen was applied in two equal splits at mid tillering, i.e., 30 days after tillering (DAT) and panicle initiation (60 DAT) stages as per treatments. Anthesis was determined when $50 \%$ of panicles were visible in the centre of the plot. The crop reached physiological maturity when $95 \%$ of spikelets had turned yellow. At panicle emergence, 12 randomly selected panicles (one from each separate plant) were tagged in each cultivar. These tagged panicles were harvested at physiological maturity and data on number of filled grains per panicle and sterility percentage were recorded. Grain yield was calculated on $14 \%$ moisture basis. Harvest index, head rice recovery and $\mathrm{B}: \mathrm{C}$ ratio were also calculated.
All the data were analysed using split plot design for analysis of variance (ANOVA) and differences among treatments were compared at $\mathrm{P} \leq 0.05$ level of significance using the IRRISTAT data analysis package (IRRI 2000).

\section{RESULTS AND DISCUSSION}

Growth parameters : The plant growth parameters showed significant variation due to the effect of sowing time (Table 1). Significantly higher plant height $(98.56 \mathrm{~cm})$, tillers $\mathrm{m}^{-2}(333.41)$ and dry matter accumulation $\left(9838 \mathrm{~kg} \mathrm{ha}^{-1}\right)$ were recorded for early sown $15^{\text {th }}$ SMW but was at par with $16^{\text {th }} \mathrm{SMW}$ while the $18^{\text {th }}$ SMW sown crop recorded the significantly lowest growth parameters. Higher growth parameters in the earlier sown rice crop were also reported by (Hussain et al., 2009; Nahar et al., 2009 and Singh et al., 2012). Haghverdian (2010) also reported lower plant height during earlier stages of crop under earlier sowing due to the effect of low environmental temperature on plants growth. However, from 60 DAT, crop sown in $15^{\text {th }}$ SMW recorded highest plant height but was at par with that sown in $16^{\text {th }}$ SMW. The increase in plant height in the crops sown on early dates during the later stages might have been due to better temperature and weather conditions experienced by the crop at later growth stages especially at the internode elongation stage which is favoured more at higher temperatures. Also early sown crops had longer vegetative and overall growth period due to which plants synthesized more photosynthates which were utilized for growth of vegetative organs of the plant. Nitrogen played a significant role in the different growth parameters (Table 1). The significantly highest plant height $(98.12 \mathrm{~cm})$, tillers $\mathrm{m}^{-2}$ (343.33) and dry matter accumulation (1006 $\mathrm{kg} \mathrm{ha}^{-1}$ ) were recorded for $\mathrm{N}_{80}$ level but was at par with $\mathrm{N}_{60}$ level. The nitrogen levels $\mathrm{N}_{40}$ and control recorded significantly lower growth parameters than $\mathrm{N}_{80}$ and $\mathrm{N}_{60}$. However, control recorded significantly lowest growth parameters among all the nitrogen levels tested. The increase in plant height with increased nitrogen levels may be attributed to the fact that nitrogen enhances the vegetative growth of plants owing to increase in cell size and meristematic activity. Enhanced tillering by increased nitrogen application might be attributed to more nitrogen supply to plant at active tillering stage. The increase in dry matter with successive nitrogen levels is due to the fact that increased nitrogen levels caused increase in plant height, tiller $\mathrm{m}^{-}$ ${ }^{2}$ which subsequently increased dry matter production. Zhilin et al. (1997) also reported increase in the plant height with successive increments of nitrogen. The results were also in accordance with the findings of Haefele et al. (2008)

Phenology: The days taken to reach flowering and harvest varied significantly among the sowing dates (Table 1).The significantly higher number of days was 
Sheeraz Ahmad Wani et al. / J. Appl. \& Nat. Sci. 8 (3): 1704 - 1709 (2016)
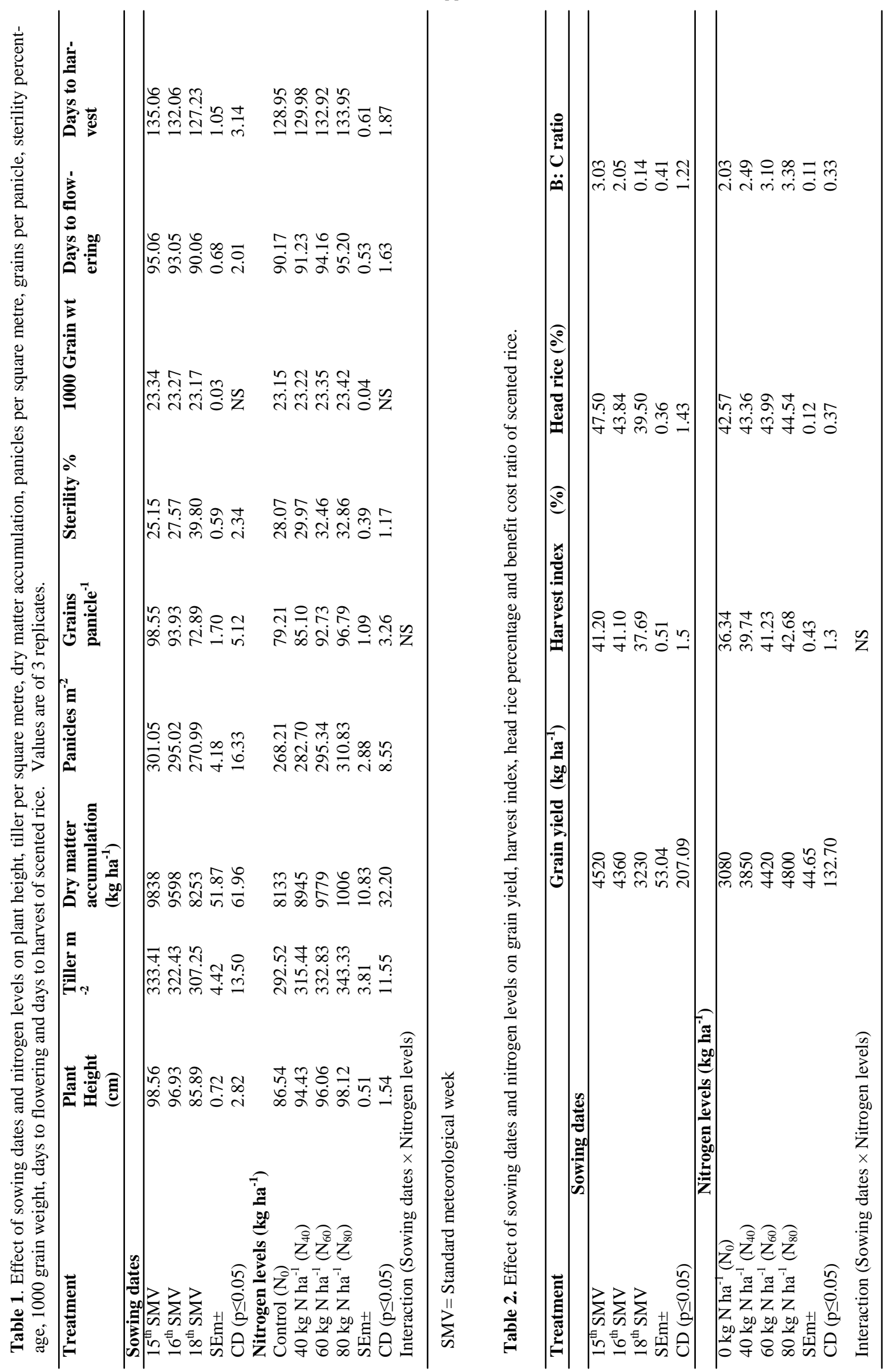

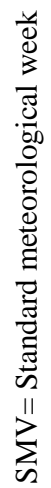


taken by $15^{\text {th }}$ SMW sown crop, however, was at par with $16^{\text {th }}$ SMW crop while the significantly lowest number of days was taken by $18^{\text {th }}$ SMW sown crop. Sowing date primarily influences the length of vegetative period of rice with early sown rice requiring a greater number of days to accumulate the same number of degree days units compared with later sown rice. A linear negative correlation between sowing dates and growth period, in the later sowing dates was also reported by Peng-fei et al. (2013). Among the nitrogen levels 80 and $60 \mathrm{~kg} \mathrm{~N}^{-1}$ took significantly more number of days to reach flowering and harvest than 40 $\mathrm{kg} \mathrm{N} \mathrm{ha}{ }^{-1}$ and control. Delayed flowering with higher nitrogen dose may be due to more vegetative growth, as reflected by increased plant height, which delayed maturity. Haque et al.( 2006) conducted an experiment to study the effect of nitrogen fertilizer on yielding ability of indigenous aromatic rice varieties with three levels of nitrogen fertilizer $\left(0,60\right.$ and $\left.120 \mathrm{~kg} \mathrm{~N} \mathrm{ha}^{-1}\right)$. They reported that irrespective of cultivars, the days required to flowering and maturity significantly increased with the increase in the amount of nitrogen applied. Crop maturity was delayed by almost 9, 6, 13 and 7days at $60 \mathrm{~kg} \mathrm{~N} \mathrm{ha}^{-1}$ and by 17, 14, 11 and 12 days at $120 \mathrm{~kg} \mathrm{~N} \mathrm{ha}^{-1}$. Accelerated vegetative growth might be a factor for delaying flowering and crop maturity with the increase in the amount of nitrogen fertilizer.

Yield attributes: Significant variation in the yield attributes was noticed among the sowing dates (Table 1). The $15^{\text {th }}$ SMW sowing date recorded significantly higher number of panicles $\mathrm{m}^{-2}(301.05)$ and grains panicle $\mathrm{m}^{-2}(98.55)$ over $18^{\text {th }} \mathrm{SMW}$ sowing date but was at par with $16^{\text {th }}$ SMW sowing. However, sterility percent, a negative yield attribute was found highest $(39.80 \%)$ in the late sowing date $\left(18^{\text {th }}\right.$ SMW). Higher panicles $\mathrm{m}^{-2}$ and grains per panicle in earlier sowing dates might be due to more favourable weather conditions during the critical growth stages like panicle initiation, flowering and grain filling periods and also due to higher tillers $\mathrm{m}^{-2}$ in earlier sown dates. The higher sterility per cent in the later sown $18^{\text {th }}$ SMW crop was due to lower number of filled grains per panicle. This might be attributed to the lower temperature prevalent during the flowering and grain filling period which caused the lower pollen germination and, consequently, increased the unfilled grains per panicle which therefore increased the sterility per cent. Hussain et al. (2009) also reported that delayed sowing under Kashmir conditions exposes the flowering period of rice to lower temperature and increases the sterility percentage considerably. Nahar et al. (2009) reported that low temperature causes various types of injuries in rice plants, but the most important one is spikelet sterility. They reported that filled grains production decreased significantly with the delay of transplanting which was due to occurrence of low temperature at anthesis and spikelet primordial formation. The 1000 -seed weight showed no significant difference among the different sowing dates is due to the fact that it is usually a stable varietal character and the management practice has less effect on its variation. Haque et al. (2006) also reported no significant change in 1000-grain weight with change in planting dates. In present study, nitrogen levels also significantly influenced different yield attributes (Table 1). A significantly higher number of panicles $\mathrm{m}^{-2}$ (310.83), and grains per panicle (96.79) were recorded for $\mathrm{N}_{80}$ but was at par with $\mathrm{N}_{60}$ level while as $\mathrm{N}_{40}$ and $\mathrm{N}_{0}$ (control) recorded lower yield attributes. The sterility percent was found highest (32.86 \%) for the $\mathrm{N}_{80}$ level and lowest for control $(28.07 \%)$. The increase in panicles $\mathrm{m}^{-2}$ observed for $\mathrm{N}_{80}$ and $\mathrm{N}_{60}$ levels might be due to the fact that highest nitrogen levels ensured better availability of nitrogen to plants during the tillering period of rice, which might have resulted in more productive tillers and consequently the panicle $\mathrm{m}^{-2}$. Increasing trend of panicle at the higher levels of nitrogen was also observed by (Awan et al., 2011). However, the higher sterility percentage recorded in the treatments received highest nitrogen doses, might be due to the reason that higher doses of nitrogen produced profuse tillering, which led to competition among the tillers and reduces the quantity of photosynthates from source to sink, which would have resulted in more number of ill-filled grains. The increase in spikelet sterility with an increase in nitrogen levels were also reported by (Manan et al., 2010). The 1000-seed weight is usually a stable varietal character and the management practice has lower effect on its variation. Haque et al. (2006) did not find any significant variation in the 1000-seed weight of rice varieties because of variation in nitrogen dosage. The interaction effect between sowing dates and nitrogen levels was however non-significant.

Grain yield and harvest index: The significantly highest grain yield $\left(4520 \mathrm{~kg} \mathrm{ha}^{-1}\right)$, and harvest index (41.20) was recorded for crop sown on $15^{\text {th }}$ SMW but was at par with $16^{\text {th }}$ SMW sown crop while the lowest grain yield $\left(3220 \mathrm{~kg} \mathrm{ha}^{-1}\right)$ and harvest index $(37.69 \%)$ was recorded from the later sown $18^{\text {th }}$ SMW crop (Table 2). Yield increase in the $15^{\text {th }}$ SMW sown crop was 3.53 and 28.53 per cent over $16^{\text {th }}$ and $18^{\text {th }}$ SMW sown crop, respectively. The higher yield in the earlier sowing dates might be attributed to the result of higher number of panicles $\mathrm{m}^{-2}$ and grains per panicle. Nahar et al. (2009) reported significant reductions in yield attributes and yields after delayed transplanting. Spikelet sterility was increased by late transplanting due to low temperature at panicle emergence stage. The important growth phases of rice crop especially the grain filling stage coincides with very low temperature resulting in very high sterility percentage thereby reduction in yield, when sown late (Hussain et al., 2009). Higher harvest index might be due to the proper crop growth and development and assimilate accumu- 
lation in the grains. Singh et al. (2012) reported that under late sown conditions there was reduction in harvest index of rice cultivars in sequence of (Shalimar Rice $1>$ Jhelum > Chenab> China 1039). The nitrogen levels also exerted a significant effect on the yield of basmati rice (Table 2). The highest grain yield (4800 $\mathrm{kg} \mathrm{ha}^{-1}$ ), and harvest index (42.68) was produced in crop received $80 \mathrm{~kg} \mathrm{~N} \mathrm{ha}^{-1}$ and was at par with $\mathrm{N}_{60}$ level but was significantly superior to $\mathrm{N}_{40}$ and control treatments. The increase in grain yield by applying 80 $\mathrm{kg} \mathrm{N} \mathrm{ha}^{-1}$ was $7.9,19.79$ and 35.83 per cent than nitrogen levels of 60,40 and $0 \mathrm{~kg} \mathrm{ha}^{-1}$, respectively. This could mainly be attributed to the increase in the number of panicles $\mathrm{m}^{-2}$ and total number of filled grains per panicle in the earlier sown dates. Bali and Uppal (1995); Awan et al. (2011) and Rao et al. (2013) also reported higher yield with successive increase in nitrogen levels. The decrease in harvest index at the lower nitrogen levels might be due to lower availability of translocates required for grain filling. The results are in conformity with those of (Awan et al., 2011). The interaction effect between sowing dates and nitrogen levels was however non-significant.

Quality and economics: Head rice recovery is one of the most important criteria of rice quality especially in basmati rice from the standpoint of marketing. A variety should posses a high turnout of whole grain (head) rice and total milled rice to fetch higher income (Webb, 1985). Head rice recovery showed a significant variation among sowing dates (Table 2). Significantly higher head rice percentage was recorded for the $15^{\text {th }}$ SMW sowing date (47.50) and lowest for the $18^{\text {th }}$ SMW sowing date (39.50). Similar results were obtained by Bali and Uppal (1995) from Ludhiana, who reported that basmati rice sown earlier had higher head rice recovery than late sown crop. As regards the different levels of nitrogen significant difference in head rice recovery was noticed (Table 2 ). The significantly higher head rice per cent was recorded for crop receiving $80 \mathrm{~kg} \mathrm{~N} \mathrm{ha}^{-1}$ (44.54) and lowest for control (41.84). The results were also in accordance with the findings of Khalid and Chaudhry (1999) who also reported improvement in the quality parameters of aromatic rice with an increase in nitrogen levels. Significant differences were noticed on the economics of Pusa Sugandh 3 among the sowing dates and nitrogen levels (Table 2). The higher B:C ratio (3.03) was recorded with sowing date of $15^{\text {th }}$ SMW. Among the nitrogen levels the highest $\mathrm{B}: \mathrm{C}$ ratio (3.38) was recorded in relation to the application of $80 \mathrm{~kg} \mathrm{~N} \mathrm{ha}{ }^{-1}$. Higher $\mathrm{B}: \mathrm{C}$ ratio in the early planted crop with application of higher nitrogen level was also reported by (Kumar and Ikrammullah, 2004) under tropical condions

\section{Conclusion}

Based on the results of the study, it is concluded that Pusa Sugandh-3 should be sown earlier in season from $15^{\text {th }}$ to $16^{\text {th }}$ SMW and with nitrogen application of $60-80$ $\mathrm{kg} \mathrm{N} \mathrm{ha}{ }^{-1}$ for realizing economically higher grain yield and profit under the temperate climatic conditions of Kashmir valley. This study will be useful to create awareness among the farming community about the optimum dose of nitrogen fertilizer $\left(80 \mathrm{~kg} \mathrm{~N} \mathrm{ha}^{-1}\right)$ and sowing date $\left(15^{\text {th }} \mathrm{SMW}\right)$ of scented rice in Kashmir valley to get maximum production and remunerative returns.

\section{REFERENCES}

Awan, T. H., Ali, R. I., Manzoor, Z., Ahmad, M. and Akhtar, M. (2011). Effect of different nitrogen levels and row spacing on the performance of newly evolved medium grain rice variety, KSK-133. J. Anim. Plant Sci. 21(2): 231-234.

Balasubramanian, V., Morales, A. C., Thiyagarajan, T. M., Babu, M. and Hai, L. H. (2000). Adaptation of the chlorophyll meter (SPAD) technology for real-time $\mathrm{N}$ management in rice: a review. International Rice Research Note (IRRN) 13(2): 28-35.

Bali, A. S. and Uppal, H. S. (1995). Effect of date of transplanting and water management practices on yield of basmati rice. Indian J. Agron. 40(20): 186-192.

Bufogle, A., Bollich, P. K., Norman, R. J., Kovar, J. L., Lindau, C. W. and Macchiavelli, R. E. (1997). Rice plant growth-and nitrogen accumulation in drill-seeded and water-seeded culture. Soil Sci. Soc. Am. J. 61: 832-839.

Gao, R. S. and Zhang, S. P. (1994). Climatic and Ecological Base of Rice Quality. Shaanxi Science and Technology Press, Xi' an (in Chinese).

Haefele, S. M., Jabbar, S. M. A., Siopongco, J. D. L. C., Tirol-Padre, A., Amarante, S. T., Cruz, P. C. and Cosici., W. C. (2008). Nitrogen use efficiency in selected rice genotypes under different water regimes and nitrogen levels. Field Crops Res. 107:137-46.

Haghverdian, M. (2010). The study of the effects of planting date on agronomy characteristics of different varieties in rice direct cultivation M.Sc thesis, Agronomy field, Islamic Azad university, Chaloos branch.

Haque, K. M. S., Khaliq, K. A., Aktar, J. and Shamsuddula, A. M. (2006).Yielding ability of aromatic rice under stacking and non-stacking conditions with different nitrogen fertilization . Int. J. Sustain. Crop Prod. 1(1): 01-05.

Hiroyuki, S., Hasegawa, T. and Iwama, I. (2002). Response of growth and yield in paddy rice to cool water at different growth stages. Field Crop Res. 73(23): 67-79.

Hussain, A., Bhat, M. A., Ganai, M. A. and Hussain, T. (2009). Influence of planting dates and spacing schedules on performance of Basmati rice Pusa Sugandh-3 under Kashmir valley conditions. Environ. Ecol. 27: 396-398.

International Rice Research Institute (IRRI). (2000). IRRISTAT for window (CD-ROM) version $4.02 \mathrm{~b}$. Los Banos, Philippines, IRRI.

Islam, M.S.H., Bhuiya, M.S.U., Rahman, S., Hussain, M. (2009). Evaluation of SPAD and LCC based nitrogen management in rice (Oryza sativa L.). Bangladesh $J$. Agric. Res. 34(4): 661-672.

Khalid, M. and Chaudhry, A. M. (1999). Impact of nitrogen levels and its application methods on yield and kernel quality of fine rice. Pak. J. Agr. Sci. 36: 1-2.

Kumar, D. R. and Ikramullah, M. (2004). Influence of nitrogen levels and planting dates on productivity and profitability 
of scented rice varieties. J. Res. ANGRAU 32(4): 5-9.

Manan, M. A., Bhuiya, M. S. U., Hossain, S. M. A. and Akhand, M. I. M. (2010). Study on phenology and yielding ability of Basmati fine rice genotypes as influenced by planting date in Aman season. Bangladesh J. Agric. Res. 35: 157-165.

Manzoor, Z., Awan, T. H., Zahid, M. A., and Faiz, F. A. (2006). Response of rice crop to different nitrogen levels. J. Anim. Plant Sci. 16: 52-55.

Nahar, K., Hasanuzzaman, M. and Majumder, R. R. (2009). Effect of low temperature stress in transplanted aman rice varieties mediated by different transplanting dates. Acad. J. Plant Sci. 2(3): 132-138.

Norman, R. J., Guindo, D., Wells, B. R. and Wilson, C. E. (1992). Seasonal accumulation and Partitioning of nitrogen-15 in rice. Soil Sci. Soc. Am. J. 56: 1521-1527.

Peng-fei, L., Zhi-hua, Z., Yan-xia, Z., Shao-hua, X., Mingzhu, J., Wen-jing, H. and Xu-hu, Z. (2013).Effects of
Sowing Date, Basic Seedling, Nitrogen Rate and Field Water on Early Rice "Liangyou9168". Adv. J. Food Sci. and Technol. 5(4): 414-417.

Rao, V. P., Subbaiah, G. and Sekhar, K. C. (2013). Response of rice varieties to high level nitrogen on dry matter production, yield and nitrogen uptake of rice. Int. J. Appl. Biol. Pharm. 4(4): 216-218.

Singh, P., Panotra, N., Singh, P., Singh, K. N. and RaihanaHabib, K. (2012). Spikelet sterility, harvest index and yield of rice (Oryza sativa.) cultivars as influenced by low temperature and transplanting dates in temperate Kashmir. Indian J. Agron. 57(4): 83-87.

Webb, B. D. (1985). Criteria of rice quality in the U.S. In: Rice Chemistry and Technology. $2^{\text {nd }}$ ed., edited by B. O. Juliano. St. Paul, MN: ACCC, pp. 403-442.

Zhilin, L., Sarker, R.S., Nayak, S. K., Ravi, I. and Li, J. L. (1997). Physiological effect of nitrogen application on aromatic rice. J. South China Agric. Univ. 18: 13-17. 